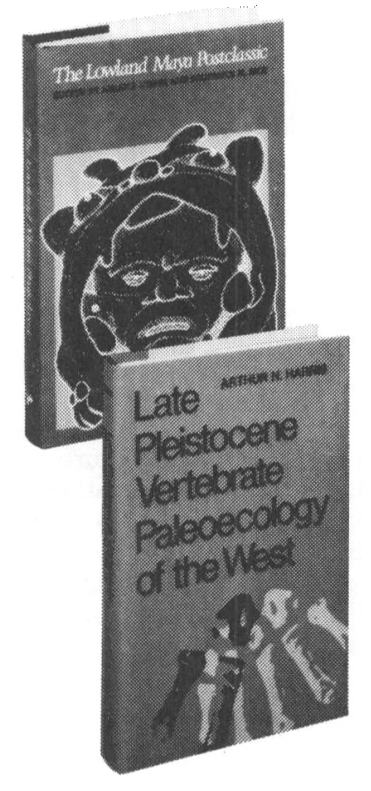

\title{
The Lowland Maya Postclassic
}

Edited by Arlen F. Chase and Prudence M. Rice

"A turning point in the study of an area and a time that are crucial to our knowledge of the Maya before and during the conquest."

-George Stuart, National Geographic Society

Through archaeological investigation and analysis as well as evaluation of ethnohistoric data, this volume presents an entirely updated picture of Postclassic Maya civilization in the Southern Lowlands. $\$ 27.50$ hardcover

\section{Late Pleistocene Vertebrate Paleoecology of the West}

By Arthur $\mathrm{H}$. Harris

Important for archaeologists, this book examines the relationships between organisms and their environments during the Pleistocene Epoch in a region ranging from the Great Plains of North America to the Pacific Ocean and from southern Canada to northern Mexico. It presents the first comprehensive, testable hypothesis concerning Late Pleistocene patterns of biotic distribution and their proximal causes in western North America. $\$ 25.00$ hardcover

Free shipping on prepaid orders. Write for a free catalog of books in anthropology and archaeology

\section{University of Texas Press} Box 7819 Austín, Texas 78713

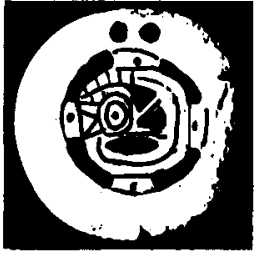

TELLICO

ARCHAEOLOGY 12,000 Years of Native American History

JEFFERSON CHAPMAN
Chapman's book about fourteen years of archaeological investigations in the Little Tennessee River Valley provides readers with a knowledge of and a feel for the rich Indian heritage of the Southeast. Archaeological methods, the processes of federal archaeology, the past environment, and each of the cultural periods, Paleo-Indian, Archaic, Woodland, Mississippian, and Cherokee, form the framework of the book. 150 pages. Illustrations. $\$ 16.95$ cloth, $\$ 8.95$ paper

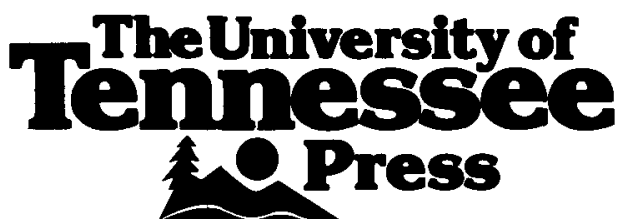

Knoxville 37996-0325 


\section{A Special Limited Offer from ACADEMIC PRESS}

\section{Two New Volumes in the STUDIES IN ARCHAEOLOGY Series Guilá Naquitz Archaic Foraging and Early Agriculture in Oaxaca, Mexico \\ Edited by KENT V. FLANNERY}

From the Preface: This is the report of an interdisciplinary study of the origins of agriculture in the southern Mexican highlands. It begins in the preagricultural era and ends with the earliest evidence for cultivated plants in the eastern Valley of Oaxaca. The disciplines employed include archaeology, botany, zoology, palynology, and computer modeling.

Contents (Section Headings): The Problem and the Model. The Cultural and Environmental Setting. Excavation and Artifact Analysis. Comparing the Archaic and Modem Environments. Analysis of Subsistence. Spatial Analysis of Living Floors. Simulating Foraging and Early Agriculture in Oaxaca. Summary and Conclusions.

September 1985, c. 533 pp., in preparation/ISBN: 0-12-259830-X Pre-publication price: $\$ 55.00^{*}$ Regular price: $\$ 95.00$ (tentative)

\section{The Upper Paleolithic of the Central Russian Plain OLGA SOFFER}

This is an ecological study of the hunter-gatherers who lived on the Central Russian plain 26,000 to 12,000 years ago. Soffer reviews the extensive Russian language literature, summarizes the biological, geological, geographical, and archaeological data from 29 major sites, and then draws on evolutionary theory, cultural ecology, and historical materialism to interpret her own fieldwork and generate a new model of human ecology in the Late Pleistocene.

Contents: Introduction. Upper Paleolithic Sites on the Central Russian Plain. The Environmental Given. Chronology and Land Use. Subsistence Practices and Duration of Occupation in Late Valdai. Site Types and the Settlement System. Socio-Political Integration on the Upper Paleolithic Central Russian Plain. Conclusions and Implications. References. Index.

October 1985, c. 635 pp., in preparation/ISBN: 0-12-654270-8

Pre-publication price: $\$ 65.00 *$ Regular price: $\$ 98.50$ (tentative)

*Pre-publication prices are good only on orders accompanied by this ad coupon received before December 31, 1985. All orders must be placed directly with ACADEMIC PRESS.

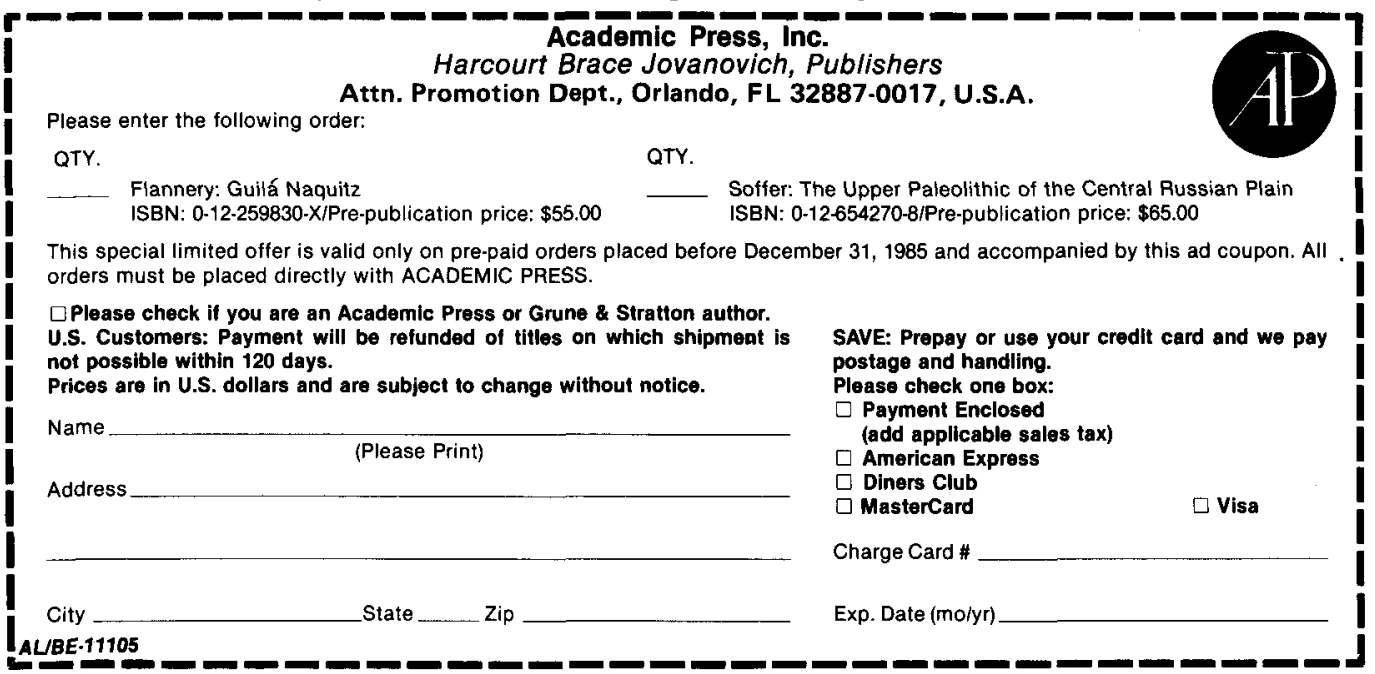


Edited by STANTON W. GREEN and STEPHEN M. PERLMAN

From the Preface: ... a diverse and innovative set of case studies that address fundamental questions conceming social change through the study of anthropological archaeology.

1985, 344 pp., \$49.50/1SBN: 0-12-298780-2

\section{A Volume in the STUDIES IN ARCHAEOLOGICAL SCIENCE Series Thermoluminescence Dating \\ M. J. AITKEN}

Contents: Introduction. Basic Pottery Dating. Thermoluminescence. Natural Radioactivity: The Annual Dose. Artificial Irradiation. Special Methods. Beyond Pottery. Sediment Dating-Solar Resetting. Appendix. References. Index.

September 1985, 384 pp., \$59.00/ISBN: 0-12-046380-6 (Cloth)

September 1985, 384 pp., \$34.95/ISBN: 0-12-046381-4 (Paper)

A Volume in the STUDIES IN HISTORICAL ARCHAEOLOGY Series

\section{The Archaeology of Slavery and Plantation Life \\ Edited by THERESA A. SINGLETON}

Contents (Section Headings): Research Strategies. Settlement. Artifact Patterns. Foodways. Afro-American Traditions. Transformation.

\section{August 1985, 360 pp., \$65.00/ISBN: 0-12-646480-4 \\ Prehistoric Europe \\ TMMOTHY CAAMPION, CLIVE GAMBLE, STEPHEN SHENNAN, and AIFSDAIR WEITTLE}

This volume presents an elementary and comprehensive synthesis of the new discoveries and the new interpretations of European prehistory.

\section{4, 376 pp., \$45.00/ISBN: 0-12-167550-5 (Cloth) 1984, 376 pp., \$23.50/ISBN: 0-12-167552-1 (Paper) \\ European Economic Prehistory A New Approach ROBIN DENNELL}

The main features of European prehistory up to the emergence of cereal crops and sheep as major resources are examined primarily in terms of the type of resources used and the type of subsistence strategy used to exploit them.

1983, 217 pp., \$27.00/1SBN: 0-12-209180-9 (Cloth)

1985, 217 pp., \$15.00/1SBN: 0-12-209182-5 (Paper)

\section{Osar Es-Seghir \\ An Archaeological View of Medieval Life \\ CHARLES L. REDMAN}

December 1985, c. 250 pp., in preparation/ISBN: 0-12-584630-4

Academic Press, Inc.

Harcourt Brace Jovanovich, Publishers

Orlando, Florida 32887, U.S.A. • 24/28 Oval Road, London NW1 7DX, U.K.

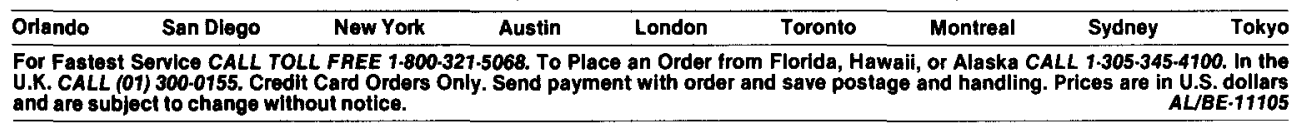




\section{Reading the Isotopic Clocks.}

Tour research in age determination and stable isotopes requires reliable data and

custom service. Teledyne Isotopes has the expertise and experience to meet these requirements.

We have been pioneers in the industry since 1955 and are the only commercial laboratory that offers all major age determination techniques.

\section{These include:}

Radiocarbon

Stable isotopes: ${ }^{13} \mathrm{C} / 12 \mathrm{C} \bullet{ }^{18} \mathrm{O} /{ }^{16} \mathrm{O} \bullet \mathrm{H} / \mathrm{D}$

$\mathbf{K} / \mathbf{A r} \bullet \mathbf{R b} / \mathbf{S r} \bullet \mathbf{U} / \mathbf{P b} \bullet \mathbf{P b} / \mathbf{P b}$
We can assure you of reliable data because of well-staffed and well-equipped labs, intercalibration with major universities and government facilities, and through use of N.B.S. and international standards.

For the most reliable reading of the isotopic clocks, come to the experts.

TATELEDYNE ISOTOPES

50 Van Buren Avenue

Westwood, NJ 07675

$201 / 664-7070$

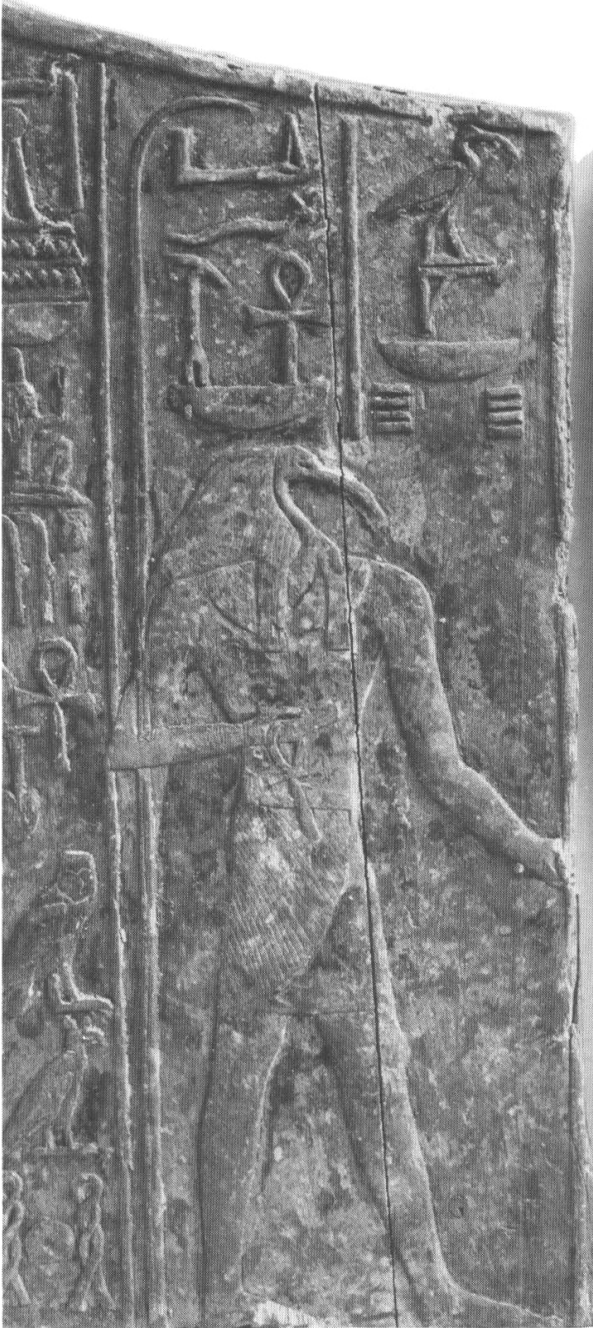

Telex: 134474

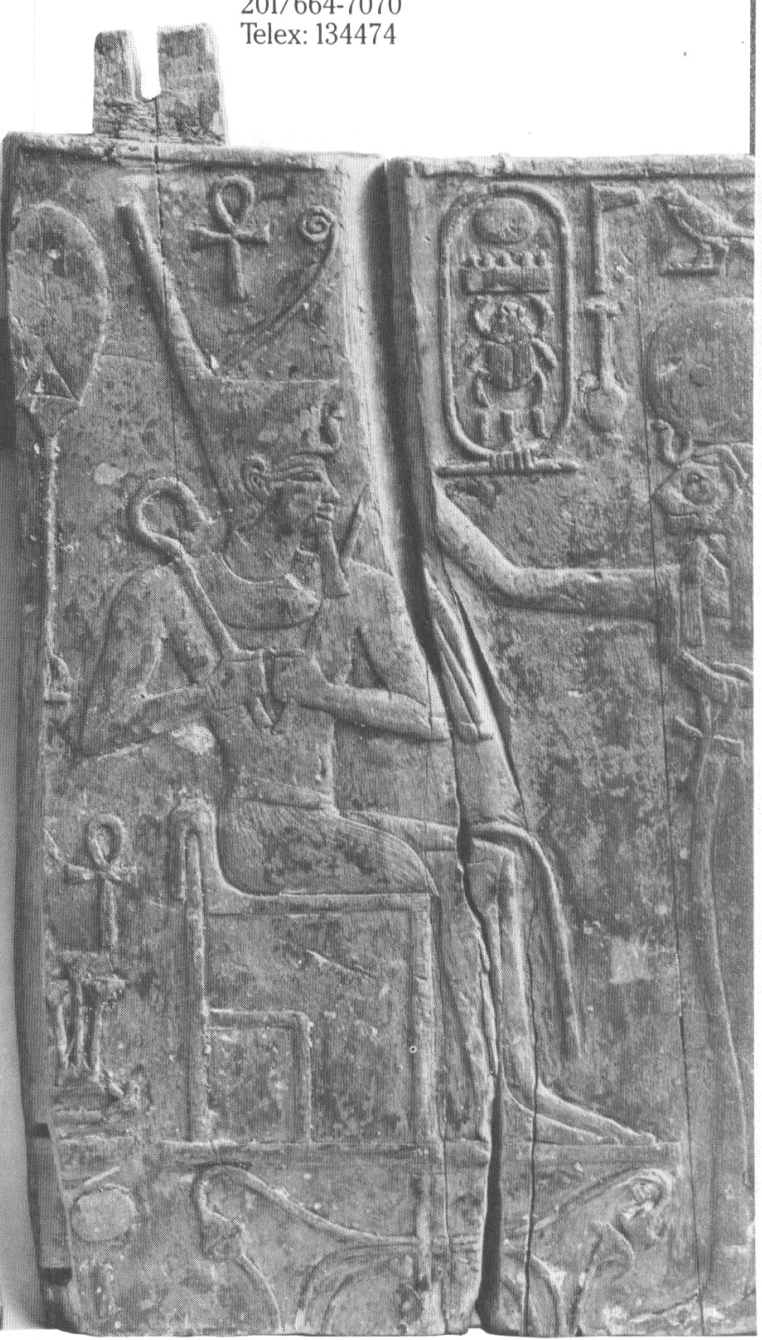


New from the Society for American Archaeology . . .

SAA Papers No. 3:

THE STRUCTURE OF MATERIAL SYSTEMS:

ETHNOARCHAEOLOGY IN THE MAYA HIGHLANDS

by Brian Hayden and Audrey Cannon

SAA Members: \$17.95 Non-members: \$24.95

Also Available:

SAA Papers No. 1

\section{MODELS AND METHODS IN REGIONAL EXCHANGE edited by Robert E. Fry}

SAA Members: $\$ 5.95 \quad$ Non-members: $\$ \mathbf{\$ 7 . 9 5}$

SAA Papers No. 2

\section{MAN AND ENVIRONMENT IN THE GREAT BASIN \\ edited by David B. Madsen and James F. O'Connell}

SAA Members: $\$ 10.95 \quad$ Non-members: $\$ 14.95$

Include payment with order to:

Society for American Archaeology

1511 K St., N.W., Suite 716

Washington, D.C. 20005

\section{DISTINGUISHED SERVICE AWARD NOMINATIONS SOLICITED}

The Distinguished Service Award established by the Society for American Archaeology is presented annually to a member for specific accomplishments of extraordinary quality. Recognition can be granted in a wide range of areas relating to archaeology including, for example, teaching (academic as well as public education), research (theory, method, application of new technology, analysis, etc.), and conservation of archaeological data (curatorial, legal, managerial), as long as two basic criteria are met. First, the contribution must be truly extraordinary in nature (not expected in the normal course of events) and must be widely recognized as such, and second, it must be of a positive and lasting quality.

The Society is accepting nominations from members for the 1986 Award, which will be presented at its Annual Meeting in April 1986, in New Orleans, LA. Each recommendation should be supported by a statement documenting concisely and thoroughly the achievements of the nominee. Mail by November 11, 1985, to Dr. George C. Frison, Chair, DSA Committee, Department of Anthropology, University of Wyoming, Box 3431, University Station, Laramie, WY 82070.

\section{1st ANNUAL MEETING \\ SOCIETY FOR AMERICAN ARCHAEOLOGY}

The Clarion Hotel

New Orleans, Louisiana

Wednesday, April 16-Saturday, April 19, 1986

Annual Meeting Chair: Robert W. Neuman, Museum of Geoscience, Louisiana State University, Baton Rouge, LA 70803-4111.

See the April 1985 issue of American Antiquity for full details of the 1986 Annual Meeting. 


\section{CONTENTS}

Coosa: A Chiefdom in the Sixteenth-Century Southeastern United States

Tribe Versus Chiefdom in Lower Central America

Debitage Analysis and Archaeological Interpretation
Charles Hudson, Marvin Smith, David Hally, Richard Polhemus, and Chester DePratter

Winifred Creamer and Jonathan Haas Alan P. Sullivan, III and Kenneth C. Rozen
Theoretical Directions in European Archaeology

Recent Research in Central Asia

Peter Bogucki

Philip L. Kohl

\section{REPORTS}

Tree-Ring Dating of Baldcypress and the Potential for Millennia-Long Chronologies in the Southeast

David W. Stahle, Edward R. Cook, and James, $\boldsymbol{K}$. C. White 796

The Third Dimension in Site Structure: An Experiment in Trampling and Vertical Dispersal

Diet and Parasitism at Dust Devil Cave

Diane P. Gifford-Gonzalez, David B. Damrosch, Debra R. Damrosch, John Pryor, and Robert L. Thunen Karl J. Reinhard, J. Richard Ambler, and Magdalene McGuffie 819

Deer Densities and Population Dynamics: A Cautionary Note

William A. Starna and John H. Relethford

Tomato Springs: The Identification of a Jasper Trade and Production Center in Southern California

Marie G. Cottrell

Middle Prehistoric Period Adaptations and Paleoenvironment in the Northwestern Plains: The Sun River Site

Sally T. Greiser, T. Weber Greiser, and Susan M. Vetter

\section{COMMENTS}

Ethnoarchaeology and Behaviorism: Comments on Gilman's Review of Ethnography by Archaeologists

Comments on Tainter and Lucas's "Epistemology of the Significance Concept"

CURRENT RESEARCH, edited by Lynne Goldstein

Central America, Mesoamerica, Northeast, Southeast, Greater Southwest

REVIEWS AND BOOK NOTES, edited by Jerald T. Milanich 